\author{
K.Zh. Kutzhanova ${ }^{1}$, A.F. Kurmanova ${ }^{1}$, I.A. Pustolaikina ${ }^{1}$, Xintai $\mathrm{Su}^{2}$ \\ ${ }^{I}$ Ye.A. Buketov Karaganda State University; \\ ${ }^{2}$ Xinjiang University, Urumqi, China \\ (E-mail: kutzhanovak@mail.ru)
}

\title{
Quantum-chemical study of aminoacetic acid cyclic dimers
}

\begin{abstract}
Cyclic dimers of aminoacetic acid were investigated by ab initio UHF 3-21G method using the Gaussian2009 program. Four types of aminoacetic acid cyclic dimers were registered by quantum-chemical method. Comparative analysis of geometry, charge and energy parameters of aminoacetic acid dimers and individual molecule was performed. Complexation energy of studied dimers was estimated.
\end{abstract}

Key words: quantum chemical calculations, ab initio UHF 3-21G, hydrogen bond, aminoacetic acid, glycine, dimers, associates, cyclic complexes by hydrogen bonding, geometric and energy parameters, charge distribution, complexation energy, hydrogen bond energy.

It is known that in real conditions a number of oxygen- and nitrogen-containing compounds forms dimers with different intermolecular interaction mechanism. Carboxylic acids, water, ammonia and other substances with a hydrogen bond refer to them [1]. As a result, between the interacting particles complexes by hydrogen bonding, geometrical parameters and energy characteristics of which influence on the acid-base properties of initial molecule are formed.

Amino acids are known to possess both acidic and basic properties.Acidic properties are attached by carboxyl group, basic ones are given by amino group [2]. Aminoacetic acid or glycine is the simplest of amino acids. In a separate molecule of glycine amino and carboxyl groups neutralize each other mutually forming bipolar ions [3]:<smiles>NCCCN[14CH2][14CH2][14CH2][14CH2][14C](=O)[O-]</smiles>

or<smiles></smiles>

The aim of this work is to study the geometric, charge and energy characteristics of hydrogen bonding cyclic complexes of aminoacetic acid by quantum chemical methods.

Quantum chemical calculations of aminoacetic acid individual molecules were carried out primarily using the program Gaussian-2009 [4]. The full optimization of the geometry was carried out in a split-valence basis set 3-21G, one of the most popular and cost-effective basis set where atomic orbitals of inner shells electrons are approximated by three Gaussian functions of the valence shell orbitals and described by the two $(\mathrm{N}=2)$ and the one $(\mathrm{P}=2)$ of the Gaussian function conformably [5].

The existence a minimum of two glycine rotamers can be assumed due to the possibility of hydroxyl group rotation around of the C-C bond (Fig. 1) [6].
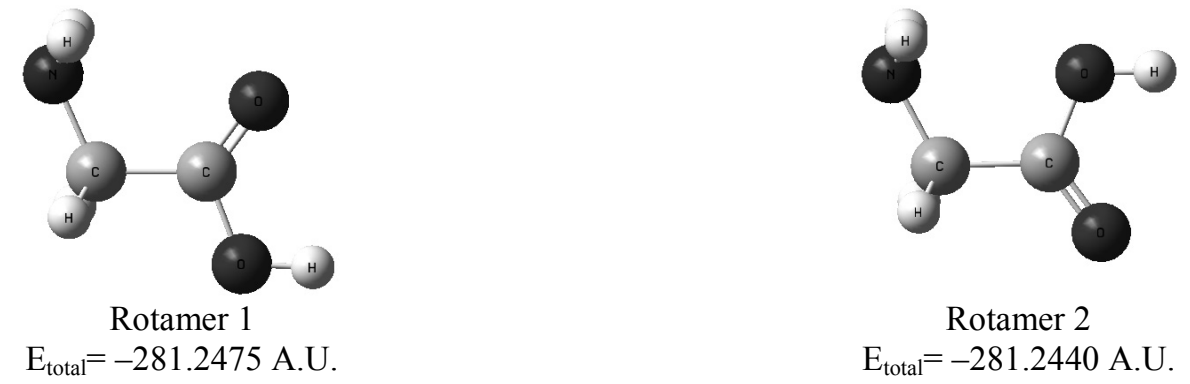

Figure 1. Rotamers of aminoacetic acid

Quantum chemical estimation of the total energies of these glycine rotamers was showed that rotamer 1 $\left(\mathrm{E}_{\text {total }}=-281.2475\right.$ A.U. $)$ is thermodynamically more stable in comparison with rotamer 2 $\left(\mathrm{E}_{\text {total }}=-281.2440\right.$ A.U.). Further calculations were performed for the rotamer 1. Geometric parameters and charge distribution for rotamer 1of aminoacetic acid are shown in Figure 2. 

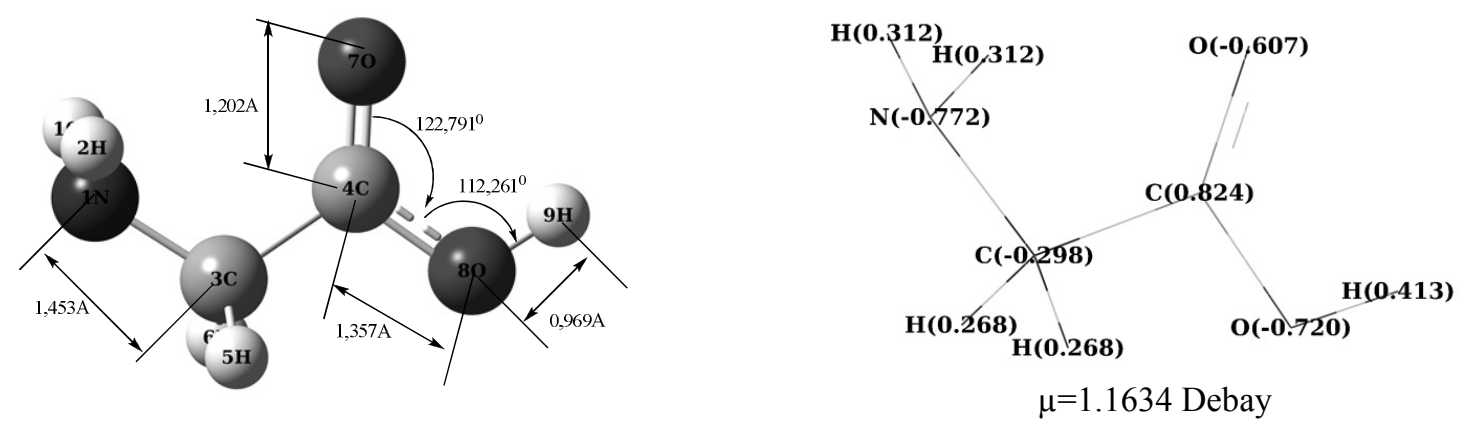

Figure 2. Geometric parameters and charge distribution for Rotamer 1of aminoacetic acid

As the Figure 2 demonstrates the charge distribution of the hydrogen atoms depends on its position in the molecule and varies depending on the functional group they belong to: the hydrogen carboxyl group has the highest positive charge $(q=0.413)$ over the hydrogen amino group $(q=0.312)$.

The similar charges on hydrogen related to nitrogen should be drawn to the fact indicating their equal and symmetrical structure. The dipole moment of the molecule according to UHF 3-21G calculations is $\mu=1.1634$ Debay. A molecule with a nonzero dipole moment is known to be called polar.

It was interested to study by quantum chemical methods the ability of aminoacetic acid for complex formation by hydrogen bonds in dimeric molecules and identify the most thermodynamic stable complexes.

Figure 3 shows the cyclic complexes by hydrogen bond formed by hydroxyl groups oriented to each other (Fig. $3 a, b$ ) and with participation of the amino groups (Fig. $3 c, d$ ).
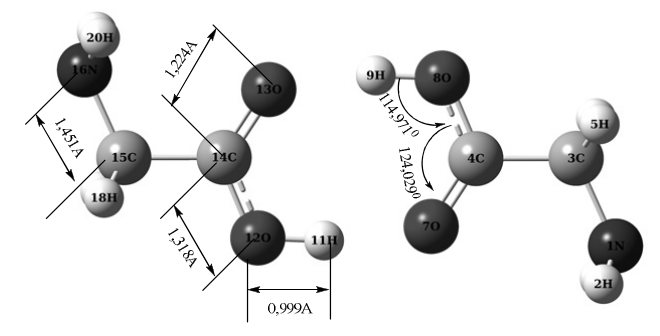

$\mathrm{E}_{\text {total }}=-562.538$ A.U.

a) Dimer 1
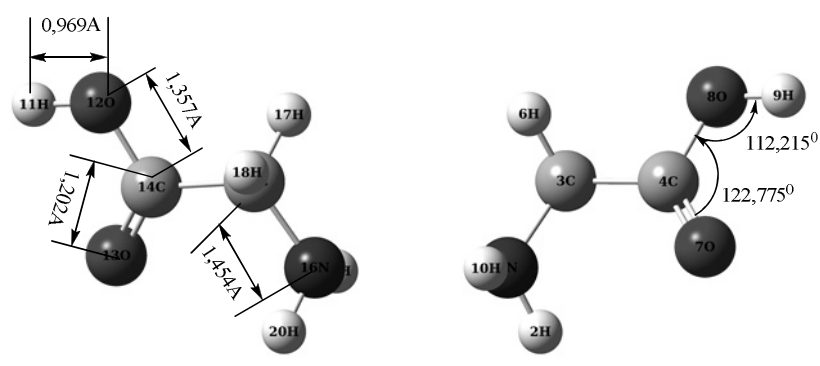

$\mathrm{E}_{\text {total }}=-562.503$ A.U.

c) Dimer 3
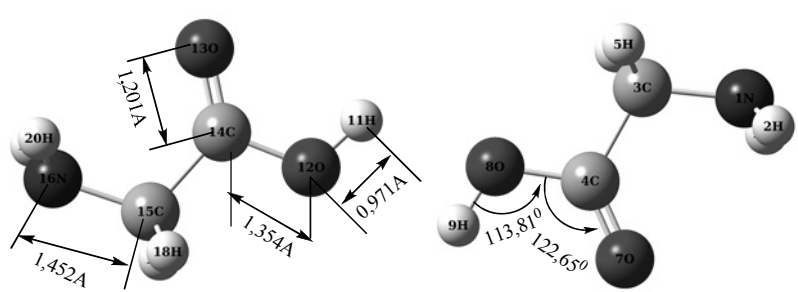

$\mathrm{E}_{\text {total }}=-562.501$ A.U.

b) Dimer 2
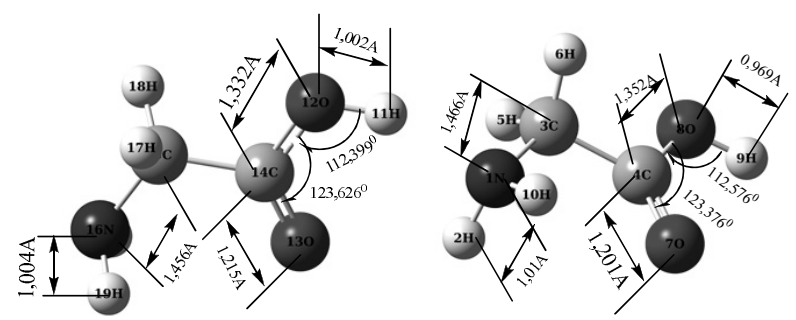

$\mathrm{E}_{\text {total }}=-562.522$ A.U.

d) Dimer 4

Figure 3. Geometric and energy parameters of aminoacetic acid cyclic dimers

Data on the Figure 3 show that Dimer 1 is thermodynamically more stable in comparison with other structures. It was interesting to compare the complexation energy of discussed dimers.

The complexation energy of the dimer can be estimated by quantum chemical methods as the difference between total energy of two individual molecules and total energy of the complex:

$\Delta \mathrm{E}_{\text {complex }}=2 \cdot \mathrm{E}_{\text {total }}($ Rotamer 1$)-\mathrm{E}_{\text {total }}($ Dimer $)=2 \cdot(-281.2475)-\mathrm{E}_{\text {total }}($ Dimer $)=562.495-\mathrm{E}_{\text {total }}($ Dimer $)$.

Original and calculated data are presented in Table 1. 
Energy characteristics of aminoacetic acid and its dimers. Calculation method - UHF 3-21G

\begin{tabular}{|c|c|c|c|c|c|}
\hline \multirow{2}{*}{ № } & \multirow{2}{*}{ Calculated structure } & \multicolumn{2}{|c|}{$-\mathrm{E}_{\text {total }}, \mathrm{A} . \mathrm{U}}$. & \multicolumn{2}{c|}{$\Delta \mathrm{E}_{\text {complex }}$} \\
\cline { 3 - 6 } & & $2 \cdot \mathrm{E}_{\text {total }}($ Rotamer 1) & $\mathrm{E}_{\text {total }}($ Dimer $)$ & A.U. & $\mathrm{kJ} / \mathrm{mol}^{*}$ \\
\hline 1 & Dimer 1 & 562.495 & 562.538 & 0.043 & 112.897 \\
\hline 2 & Dimer 2 & 562.495 & 562.501 & 0.006 & 15.753 \\
\hline 3 & Dimer 3 & 562.495 & 562.503 & 0.008 & 21.004 \\
\hline 4 & Dimer 4 & 562.495 & 562.522 & 0.027 & 70.889 \\
\hline
\end{tabular}

* 1 A.U. $=2625.5 \mathrm{~kJ} / \mathrm{mol}$.

Table 1 shows that the maximum energy of complexation is fixed for Dimer 1. It is also the most thermodynamically stable dimer. It should be noted the specific structure of the Dimer 1, which reminds chelate geometry and involves two hydrogen bonds formed by hydroxyl groups of both aminoacetic acid molecules. Structure of Dimer 1 is differs by planarity and symmetry against other associates.

Complexation energy of glycine dimers varies from $15.752 \mathrm{~kJ} / \mathrm{mol}$ to $112.897 \mathrm{~kJ} / \mathrm{mol}$. This value is comparable with the experimental data of hydrogen bond energy, which is varies widely from 1 to $160 \mathrm{~kJ} / \mathrm{mole}$, but generally hydrogen bonds are much weaker than covalent bonds [7].

The difference in the relative position of two identical aminoacetic acid molecules affects strongly the values and geometric characteristics of the considered complexes. It was interesting to see how change the dimers geometrical characteristics according to mutual orientation of the glycine molecules. Geometric characteristics of aminoacetic acid and its dimers are shown in Table 2.

Table 2

\section{Geometric characteristics of aminoacetic acid and its dimers}

\begin{tabular}{|c|c|c|c|c|c|}
\hline Characteristic & Aminoacetic acid & Dimer 1 & Dimer 2 & Dimer 3 & Dimer 4 \\
\hline $\mathrm{R}(\mathrm{O} 8 \mathrm{H} 9), \AA$ & 0.9690 & 0.999 & 0.971 & 0.969 & 0.969 \\
\hline $\mathrm{R}(\mathrm{O} 8 \mathrm{C} 4), \AA$ & 1.357 & 1.318 & 1.354 & 1.357 & 1.352 \\
\hline $\mathrm{R}(\mathrm{O} 7 \mathrm{C} 4), \AA$ & 2.202 & 1.224 & 1.201 & 1.202 & 1.201 \\
\hline $\mathrm{R}(\mathrm{C} 3 \mathrm{~N} 1), \AA$ & 1.453 & 1.451 & 1.452 & 1.454 & 1.466 \\
\hline $\mathrm{R}(\mathrm{C} 3 \mathrm{~N} 1), \AA$ & 1.003 & 1.00338 & 1.00378 & 1.00443 & 1.007 \\
\hline$\angle(\mathrm{C} 4 \mathrm{O} 8 \mathrm{H} 9))^{\circ}$ & 112.261 & 114.971 & 113.81 & 112.215 & 112.576 \\
\hline$\angle(\mathrm{O} 7 \mathrm{C} 4 \mathrm{O} 8))^{\circ}$ & 122.974 & 124.029 & 122.65 & 122.775 & 123.376 \\
\hline
\end{tabular}

Evidently in Figure 2 the involvement in the formation of cyclic complex by hydrogen bond of the carboxyl group integrally (Dimer 1) leads to an increase in the interatomic distances R(O8H9) and R(O12H11) and bond angles with the atoms involved in the formation of intermolecular hydrogen bonds as opposed to a single molecule (Table 2). The analysis of the geometric characteristics of dimer 2 where only OH-groups of carboxyl groups were involved also shows their increase and might be inerpreted in favor of dimer structures stability.

While comparing geometric characteristics of dimers peak value belongs to structure 1. Similar dependence might indicate less strong interatomic reaction in a molecule, and, therefore, stronger intermolecular reactions in appropriate dimers because of high hydrogen mobility. It was interesting to observe changes in geometrical parameters of Dimer 4, wherein hydrogen bonds were formed by interaction between carboxyl group of one molecule and amino group of another molecule. In the «acid» molecule the bonds of $\mathrm{OH}, \mathrm{C}=\mathrm{O}$ are longer and $\mathrm{NH}, \mathrm{NC}, \mathrm{C}-\mathrm{O}$ bonds are shorter in comparison with the «basic» one. Similar relationships can be traced to the values of valent and dihedral angles.

Table 3 shows charge distribution and dipole moments for studied dimers of aminoacetic acid. Table 3 shows that although the total charge of each structure is equal to 0 the dipole moment is increased from Dimer 1 to Dimer 4. It should be noted a small well-compensated dipole moment of the Dimer 1, that is possible due to the specific symmetric structure of this cyclic complex.

Moreover, the charges on the atoms participating in creation of hydrogen bond complex are higher than those untapped in complexation. Hence, the charge on H11 (H9) in Dimer 1 is 0.471 Debay and in Dimer 3 the given characteristic is reduced to 0.413 Debay, and 0.419 Debay in dimer 4. Similarly the charge on $\mathrm{H}_{20}\left(\mathrm{H}_{19}\right)$ and $\mathrm{H}_{2}\left(\mathrm{H}_{10}\right)$ changes from 0.312 Debay in Dimer 1 to 0.366 Debay in Dimer 4. 
Table 3

Charge distribution and dipole moments for studied dimers of aminoacetic acid

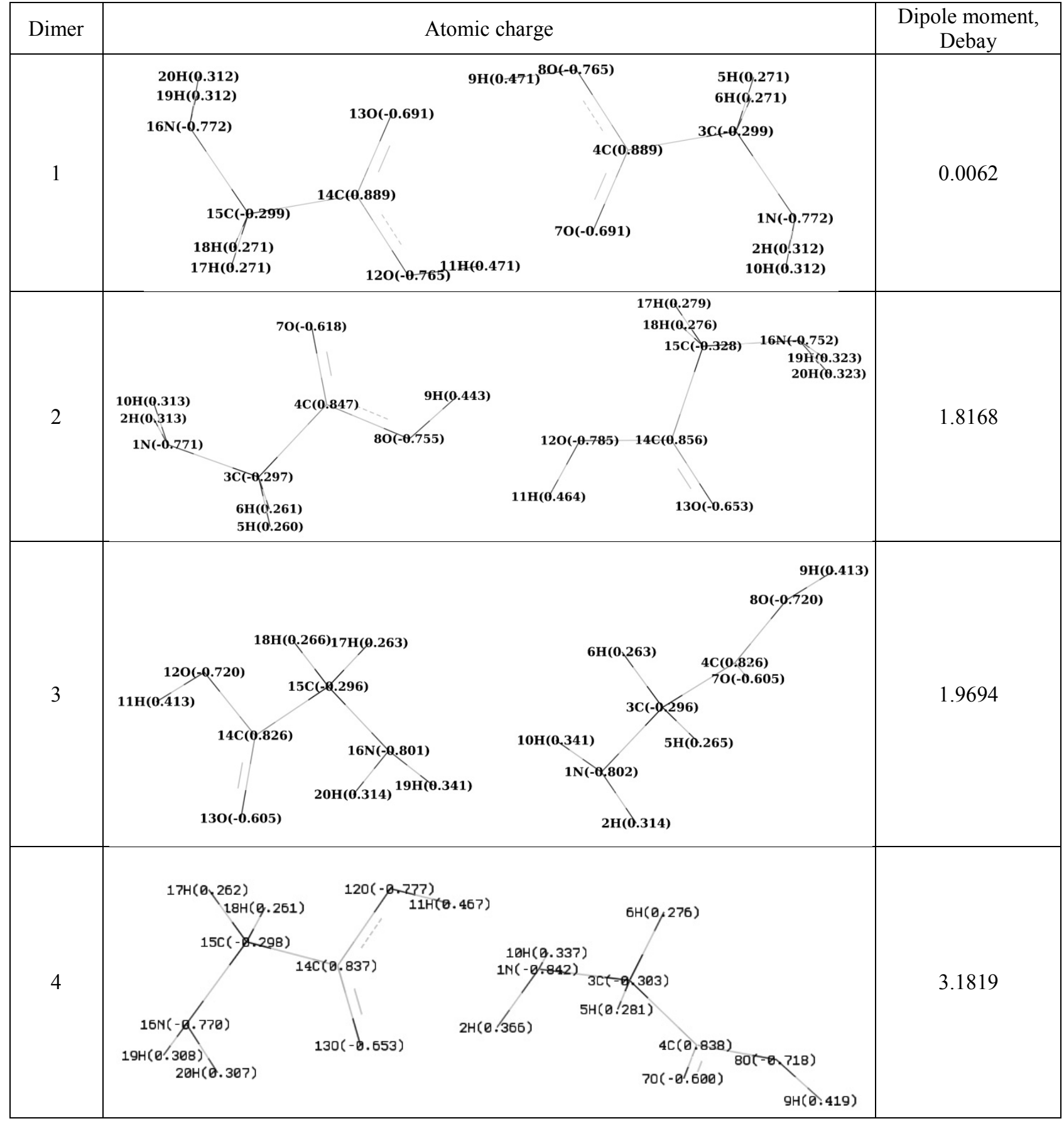

Thus cyclic dimers of aminoacetic acid were investigated by ab initio UHF 3-21G method using the Gaussian-2009 program. Four types of aminoacetic acid cyclic dimers were registered by quantum-chemical method. Comparative analysis of geometry, charge and energy parameters of aminoacetic acid dimers and individual molecule was performed. Complexation energy of studied dimers was estimated.

It was shown that complexation energy of glycine dimers varies from $15.753 \mathrm{~kJ} / \mathrm{mol}$ to $112.897 \mathrm{~kJ} / \mathrm{mol}$. This value is comparable with the hydrogen bond energy. Maximum energy of complexation is fixed for Dimer 1. It is also the most thermodynamically stable dimer. It was noted the specific structure of the Dimer 1, which reminds chelate geometry and involves two hydrogen bonds formed by hydroxyl groups of both aminoacetic acid molecules. 


\title{
References
}

1 Pimentel G.C., McClellan A.L. The hydrogen bond. - San Francisco: W.H. Freeman, 1960. - 475 p.

2 Vladimirov Y.A. Physico-chemical properties of amino acids and peptides // Journal of General Chemistry. — 2010. Vol. 80, No. 2. - P. 425-430.

3 Bonaccorsi R., Palla P., Tomasi J. Conformational energy of glycine in aqueous solutions and relative stability of the zwitterionic and neutral forms. An ab initio study // Journal of the American Chemical Society. — 1984. - Vol. 106, No. 7. P. 1945-1950.

4 Frisch M.J., Trucks G.W., Schlegel H.B. Gaussian 09, Revision C.01. — Wallingford: Gaussian, Inc., 2009. — 245 p.

5 Binkley J.S., Pople J.A., Hehre W.J. Self-consistent molecular orbital methods. 21. Small split-valence basis sets for first-row elements // Journal of the American Chemical Society. — 1980. - Vol. 102, No. 3. — P. 939-947.

6 Suenram R.D., Lovas F.J. Millimeter wave spectrum of glycine. A new conformer // Journal of the American Chemical Society. - 1980. - Vol. 102, No. 24. - P. 7180-7184.

7 Smith J.D. et al. Energetics of hydrogen bond network rearrangements in liquid water // Science. — 2004. - Vol. 306, No. 5697. - P. 851-853.

\section{К.Ж. Кутжанова, А.Ф. Курманова, И.А. Пустолайкина, Ксинтай Су}

\section{Аминсірке қышқылының циклді димерлерін квантты-химиялық зерттеу}

Мақалада Gaussian-2009 бағдарламалық кешенінің UHF ab initio 3-21G әдісі көмегімен аминсірке қышқылының циклді димерлері зерттелді. Аминсірке қышқылының циклді димерлерінің төрт түрі квантты-химиялық анықталды. Димерлердегі және жеке аминсірке қышқылының молекуласындағы зарядтардың таралуына, геометриялық және энергиялық өлшемдеріне салыстырмалы талдау жүргізілді. Зерттеліп отырған димерлердің кешентүзілу энергиялары бағаланды.

\section{К.Ж. Кутжанова, А.Ф. Курманова, И.А. Пустолайкина, Ксинтай Су \\ Квантово-химическое изучение циклических димеров аминоуксусной кислоты}

\begin{abstract}
В статье исследованы циклические димеры аминоуксусной кислоты UHF ab initio 3-21G методом с помощью программного комплекса Gaussian-2009. Квантово-химически идентифицированы четыре типа циклических димеров аминоуксусной кислоты. Выполнен сравнительный анализ геометрических и энергетических параметров, распределения зарядов в димерах и отдельной молекуле аминоуксусной кислоты. Для исследуемых димеров оценена энергия комплексообразования.
\end{abstract}

